\title{
SOSIALISASI DAN PELATIHAN PEMBUATAN SIRUP MARKISA DAN MASKER LIMBAH BUAH MARKISA PADA KELOMPOK PKK KELURAHAN LAU CIH DAN SIDOMULYO DI KOTA MEDAN
}

\author{
Suswati $^{*}$, Asmah Indrawati ${ }^{1}$, Beby Masitoh $^{2}$ \\ 1* Fakultas Pertanian, Universitas Medan Area, Medan, Indonesia \\ ${ }^{2}$ Fakultas Ilmu Sosial dan Ilmu Politik, Universitas Medan Area, Medan, Indonesia \\ "Penulis Korespondensi: suswatifebri@gmail.com
}

\begin{abstract}
Abstrak
Kelurahan Lau Cih dan Sidomulyo merupakan dua kelurahan di Kecamatan Medan Tuntungan yang terbanyak partisipasi rumah tangga dalam usaha pertanian. Sebanyak $20 \%$ kelompok wanita berperan di bidang pertanian. Pada kegiatan pengabdian kepada masyarakat sebelumnya, Kelompok PKK Kelurahan Lau Cih dan Sidomulyo telah dilatih untuk melakukan penanaman tanaman markisa dataran rendah dalam rangka pemanfaatan pekarangan. Tanaman markisa tumbuh subur dan menghasilkan buah dalam jumlah besar, tetapi buah markisa yang dipanen hanya dimakan dalam bentuk segar. Kurangnya informasi dan keterampilam kelompok PKK dalam pengolahan buah markisa hingga kini buah markisa masih dijual dalam bentuk segar. Tujuan kegiatan adalah: 1. Sosialisasi pengolahan buah markisa menjadi sirup markisa. 2. Melatih kelompok PKK dalam pengemasan produk sirup markisa.3. Melatih kelompok PKK untuk mampu mengolah limbah buah markisa (kulit buah dan biji markisa) menjadi bedak dingin kulit markisa. Kegiatan IPTEKS ini telah dilaksanakan pada 2 kelompok PKK kelurahan Lau Cih dan Sidomulyo yang masing-masing diikuti 20 orang wanita PKK. Metoda yang digunakan untuk memecahkan masalah diatas adalah dengan memberikan pengetahuan dan pelatihan maupun tekhnologi pengolahan sirup markisa dan limbahnya dilanjutkan dengan pembinaan yang dilakukan secara periodik melalui koordinasi dengan ketua kelompok wanita PKK.Hasil yang diperoleh adalah peningkatan pengetahuan dalam pengolahan sirup markisa, pengemasan produk sirup markisa, pengolahan limbah markisa menjadi bedak dingin kulit markisa dan scrub biji markisa.
\end{abstract}

Kata kunci: Lau Cih, Sidomulyo, kelompok wanita PKK, markisa kuning, sirup markisa, pengemasan, pekarangan

\begin{abstract}
Lau Cih and Sidomulyo are the two urban villages in Medan Tuntungan sub-district with the highest share of household participation in agriculture. As many as 20\% of women's groups play a role in agriculture. In previous community service activities, the PKK Group of Lau Cih and Sidomulyo Villages have been trained to plant lowland passion fruit plants in order to utilize the yard. Passion plants thrive and produce large amounts of fruit, but harvested passion fruit is eaten only in fresh form. Lack of information and skills of PKK groups in the processing of passion fruit until now passion fruit is still sold in fresh form. The purpose of the activities are: 1. Socialization of passion fruit processing into passion fruit syrup. 2. Training PKK groups in packing of passion fruit syrup.3. Train PKK groups to be able to process passion fruit waste (fruit peel and passionfruit seed) into a cool powder of passion fruit ski. This IPTEKS activity has been carried out in two groups of PKK Lau Cih and Sidomulyo villages, each of which followed by 20 women. The method used to solve the above problem is to provide knowledge and training as well as technology of passionfruit syrup processing and waste followed by coaching conducted periodically through coordination with the leader. The obtained is the increase of knowledge in the processing of passion fruit syrup, packing passion fruit syrup, Passion fruit waste treatment into a cool powder of passion fruit skin.
\end{abstract}

Keywords: Lau Cih, Sidomulyo, PKK women group, yellow passion fruit, passion fruit syrup, packing, yard 


\section{PENDAHULUAN}

Markisa adalah salah satu buah lokal yang sangat potensial untuk dikembangkan. Hal ini disebabkan karena tanaman markisa memiliki berbagai keunggulan diantaranya: budidaya markisa tergolong mudah, tidak banyak perawatan, tahan terhadap hama dan penyakit dan dapat tumbuh di dataran tinggi dan dataran rendah serta buah markisa mengandung zat gizi yang tinggi,.Markisa banyak mengandung glikosida passiflorine dan alkaloid yang berguna untuk menenangkan syaraf, selain itu buah markisa merupakan sumber pro-vitamin A, niacin, riboflavin dan vitamin $\mathrm{C}$.

Tanaman markisa kuning (Passiflora flavicarva) adalah jenis markisa yang tumbuh subur di daratan rendah (0-800 m dpl) (Iptek, 2003). Produksi markisa kuning masih sangat rendah (BPS, 2011). Produksi markisa kuning dari pertanaman rakyat bervariasi antara 5-10 ton ha per tahun, padahal produksi tersebut dapat ditingkatkan sampai 15 ton per ha per tahun. Peningkatan produksi markisa kuning juga dapat dilakukan melalui peningkatan partisipasi keluarga dalam gerakan bertanam markisa kuning di pekarangan.

Kelurahan Lau Cih dan Sidomulyo merupakan dua kelurahan di Kecamatan Medan Tuntungan yang terbanyak partisipasi rumah tangga dalam usaha pertanian. Hampir 20\% kelompok wanita berkecimpung di bidang pertanian. Kelompok wanita mengalokasikan waktunya 5-6 jam untuk bekerja di usaha pertanian milik sendiri atau orang lain. Waktu ini dapat dimanfaatkan oleh kelompok wanita yang tergabung dalam kelompok PKK untuk mengolah buah markisa menjadi bahan jadi seperti sirup dan pengolahan limbah markisa menjadi bedak dingin/masker kulit markisa. Masker tradisional lebih dikenal dengan sebutan BEDAK DINGIN. Bedak dingin (masker) berfungsi untuk menghaluskan kulit. Berbagai jenis bedak dingin dapat ditemukan sebagai usaha rumah tangga di beberapa keluarga di Kelurahan Lau Cih dan Sidomulyo, tetapi bedak dingin berbahan baku kulit markisa dan biji markisa belum pernah dilakukan oleh warga setempat.Pengolahan buah markisa menjadi sirup markisa dan pengolahan limbahnya menjadi bedak dingin dan scrub diharapkan dapat meningkatkan nilai jual buah markisa di dua kelompok PKK tersebut.

Dalam rangka meningkatkan pengetahuan dan ketrampilan kelompok wanita PKK dalam pengolahan buah markisa dan limbahnya maka telah dilaksanakan kegiatan pengabdian kepada masyarakat (PPM) berupa program transfer ilmu dan teknologi berbasis keluarga dengan menerapkan pengolahan markisa kuning menjadi sirup markisa dan pengolahan limbahnya menjadi bedak dingin. Kegiatan ini dapat dijadikan sebagai wirausaha baru bagi kelompok wanita PKK.

\section{BAHAN DAN METODE}

Metode pendekatan pada program yang akan dilaksanakan adalah:

\section{Penyuluhan}

Penyuluhan merupakan cara yang paling tepat dalam memberikan pengetahuan kepada masyarakat untuk memantapkan pelaksanaan kegiatan dan hasil penyuluhan. Brosur-brosur tentang metoda sederhana cara pengolahan buah markisa menjadi sirup dan pengolahan limbahnya menjadi masker (bedak dingin) dan scrub yang bermutu dan dibagikan kepada peserta sebelum pelaksanaan penyuluhan berlangsung.

2. Demonstrasi dan Pelatihan

a. Memperagakan/mempercontohkan bagaimana cara pengolahan buah menjadi sirup markisa

b. Memperagakan cara pengolahan limbah kulit markisa menjadi bedak dingin/masker

c. Memperagakan cara pengolahan biji markisa menjadi scrub markisa

3. Bimbingan Kelompok PKK

Anggota PKK yang telah mulai menerapkan tekhnologi ini akan dibimbing dengan pembinaan yang akan dilakukan secara periodik melalui koordinasi dengan ketua kelompok.

4. Diskusi dan Konsultasi

Pada saat penyuluhan/percontohan dan pembinaan selalu diadakan diskusi dan konsultasi untuk lebih memantapkan kegiatan pengabdian kepada masyarakat yang dilaksanakan.

Berikut ini adalah beberapa tahapan pelaksanaan kegiatan sosialisasi dan pelatihan pengolahan sirup markisa dan pengolahan limbah menjadi bedak dingin/masker dan scrub markisa.

\section{Pembentukan Khalayak Sasaran dan Penyampaian Materi}

Khalayak sasaran dalam kegiatan ini adalah anggota kelompok wanita PKK dan aparat kelurahan (kepala lingkungan) Kelurahan Lau Cih dan Kelurahan Sidomulyo. Kelompok PKK mengikutsertakan masing-masing 20 orang dan Kepala lingkungan sebanyak 8 orang (masing-masing 4 orang dari setiap kelurahan). Kegiatan sosialisasi dan pelatihan pengolahan sirup markisa dan pengolahan limbahnya dilakukan di masing-masing kelurahan dengan materi yang sama. Setiap kelompok dibagi menjadi 2 kelompok kecil (beranggotan 10 orang).

Pelatihan dibagi dalam 4 tahap yaitu penjelasan teori, latihan pemilihan buah markisa yang berkualitas sebagai sumber sirup markisa, pembuatan sirup dan pembuatan bedak dingin. Penjelasan teori diberikan oleh 2 orang instruktur. Teori menyangkut pengolahan sirup markisa: a) Bahan dan peralatan yang digunakan. b) pemilihan buah markisa yang berkualitas sebagai sumber sirup markisa. c) Pengolahan buah markisa menjadi sirup. d) Pembotolan sirup markisa. e) Pelabelan sirup markisa. Teori pengolahan limbah yaitu kulit markisa menjadi bedak dingin/masker markisa. 
Sebagai alat bantu digunakan materi pelatihan berupa pedoman pengolahan sirup markisa dan limbahnya yang dibagikan kepada masing-masing peserta dan banner mengenai tehnik pembuatan sirup markisa (Gambar 1). Untuk memudahkan instruktur dalam penyampaian materi secara lengkap kepada peserta serta memudahkan peserta untuk memahami masingmasing tahapan dalam pengolahan sirup markida dan limbahnya maka materi disampaikan dalam bentuk power point.

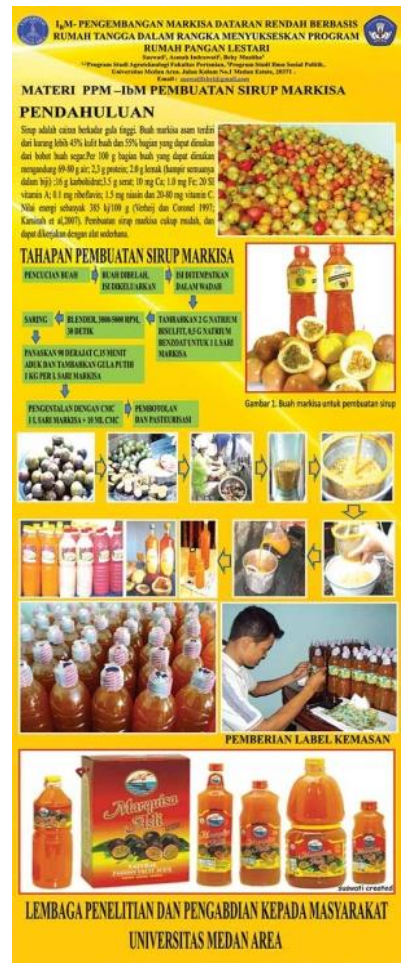

Gambar 1. Poster/banner pengolahan sirup markisa

\section{Pelaksanaan}

\section{Sosialisasi dan penyuluhan pengolahan sirup} markisa

Kegiatan sosialisasi dan pelatihan budidaya dilakukan di masing-masing kelurahan dengan materi yang sama. Setiap kelompok dibagi menjadi 2 kelompok kecil (beranggotan 10 orang). Pelatihan dibagi dalam 4 tahap yaitu penjelasan teori, latihan pemilihan buah markisa yang berkualitas sebagai sumber sirup markisa, pembuatan sirup dan pembuatan bedak dingin. Penjelasan teori diberikan oleh 2 orang instruktur. Teori menyangkut pengolahan sirup markisa: a. Bahan dan peralatan yang digunakan. b. pemilihan buah markisa yang berkualitas sebagai sumber sirup markisa.c. Pengolahan buah markisa menjadi sirup.d. Pembotolan sirup markisa.e.Pelabelan sirup markisa. Teori pengolahan limbah yaitu kulit markisa menjadi bedak dingin/masker markisa. Kegiatan-kegiatan PPM IbM pada saat pembukaan dan penyampaian materi I dapat dilihat pada Gambar 2.
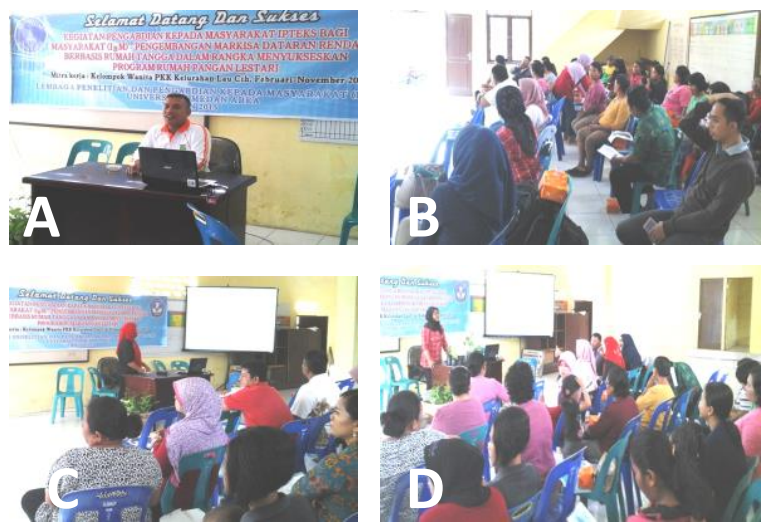

Gambar 2. Kegiatan pelaksanaan PPM IbM di Kelurahan Lau Cih. Keterangan A. Kata pengarahan sekaligus membuka acara oleh Bapak Lurah Lau Cih. B.Peserta dengan tekun mengikuti acara. C. Pemateri I. Ir. Asmah Indrawaty.MP; D. Pemateri II. Dr.Ir.Suswati.MP.Suswati.Dokumentasi.

\section{a. Pembuatan Sirup Markisa}

Buah yang digunakan berasal dari buah yang matang dipohon dengan ciri-ciri kulit buah berwarna kekuning-kuningan atau kira-kira 90-100 \% kuning. Buah tersebut dipetik langsung dari pohon kemudian buah siapkan dengan tahapan berikut:

1) Mencuci buah markisa yang masak penuh, karena akan berpengaruh pada kenikmatan rasanya.

2) Membelah buah markisa dan isinya dikeluarkan / kumpulkan isinya pada bak/ baskom.

3) Membersihkan isi markisa dari dari urat buah yang tadinya menjadi untaian biji- biji.

4) Memblender isi markisa dalam waktu yang relatif singkat (sampai dengan lendirnya lepas dari biji, tetapi tanpa menghancurkan isinya.

5) Menyaring biji serta lendirnya tadi dengan saringan kasar, untuk mendapatkan ekstrak buah yang dikehendaki, yang berupa cairan sari buah markisa.

6) Mengekstrak saring dengan kain kasa.

7) Memblender ekstrak selama satu menit menggunakan blender ukuran $1 \mathrm{~kg}$ atau $2 \mathrm{~kg}$.

8) Menambahkan natrium benzoat sebanyak $1 \mathrm{~g}$ perliter ekstrak.

9) Memasak air dengan perbandingan $250 \mathrm{cc}$ per $1 \mathrm{~kg}$ gula pasir, selanjutnya memasukan gula sedikit demi sedikit

10) Aduk terus sampai hampir mengkristal.

11) Setelah dianggap cukup, masukanlah ekstrak buah markisa pada adonan gula yang sudah masak tersebut.

12) Aduk terus sampai menunggu panas mencapai $70^{\circ} \mathrm{C}$. Diupayakan jangan sampai mendidih, karena bila sampai mendidih akan menghilangkan rasa dan aromanya.

13) Diamkan sampai dingin.

14) Bila sudah dingin maka masukkan CMC sebagai pengental secukupnya dengan cara mengabutkannya sedikit demi sedikit 
menggunakan penyaring tepung. CMC jangan diberikan pada saat sirup masih panas, karena akan hilang tidak punya pengaruh apa-apa.

15) Disimpan minimal 2 jam, baru dikemas sesuai keinginan.

\section{b. Pengemasan Sirup Markisa}

Pembotolan dan pasteurisasi. Ukuran botol yang digunakan adalah $600 \mathrm{ml}$ dan botol terbuat dari bahan plastik. Botol diangkat dari air panas dan dibalikkan agar airnya keluar dari botol. Ketika botol masih panas, sirup yang masih panas dimasukkan ke dalam botol dengan bantuan corong sampai permukaan sirup $2 \mathrm{~cm}$ dari bibir botol paling atas, kemudian botol segera ditutup dengan penutup botol. Sirup yang telah jadi langsung dimasukkan kedalam botol yang telah disterilisasikan.Kegiatan praktek pengolahan buah markisa menjadi sirup markisa dapat dilihat pada Gambar 3

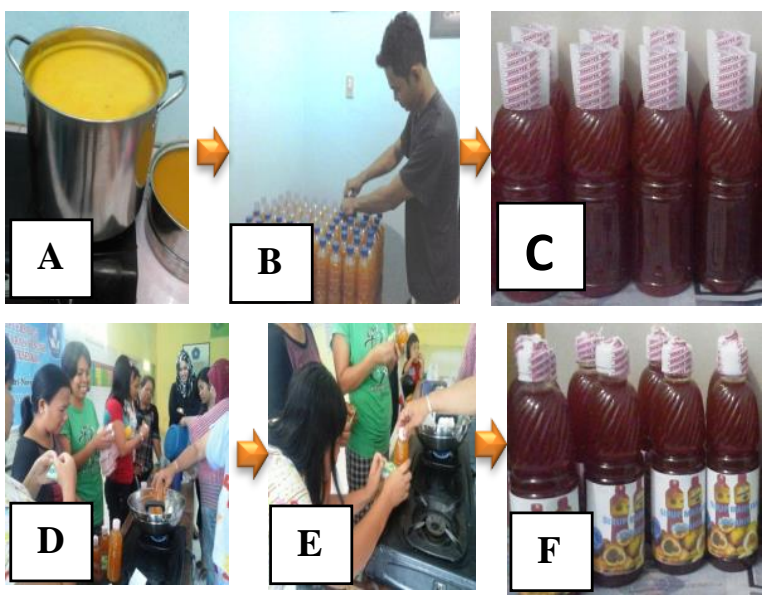

Gambar 3. Kegiatan pembuatan sirup markisa di kelompok PKK di Kelurahan Lau Cih dan Kelurahan sidomulyo. Keterangan A. Pemanasan cairan sirup dan pendinginan.B. Pengisian sirup ke dalam botol.C. Pemasangan sealer plastik. D. Perekatan sealer plastik dengan uap panas. E. Pemasangan label sirup. F.Sirup yang siap untuk dipasarkan. Suswati.Dokumentasi.

\section{c. Penyegelan}

Botol sirup Markisa yang sudah siap kemudian disegel dengan plastic khusus lalu dilekatkan dengan dryer atau dicelup ke dalam air yang mendidih.

\section{d. Pelabelan Sirup Markisa}

Pelabelan berfungsi sebagai sumber informasi mengenai produk kemasan yang berisi nama produk, Sertifikasi Produksi Pangan Industri Rumah Tangga (SPP-IRT) dan komposisi bahan sirup markisa serta Nomor BPOM produk. Design produk sirup markisa di dua kelompok PKK tersebut dapat dilihat pada Gambar 4

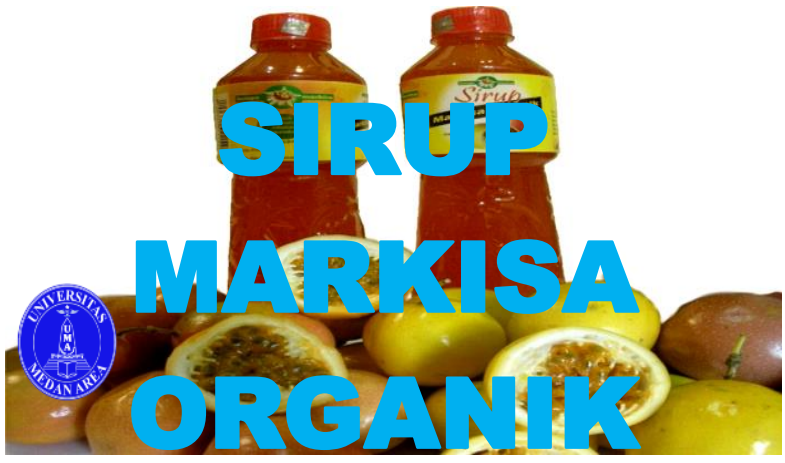

Gambar 4. Design produk sirup Markisa kelompok PKK Sidomulyo dan Lau Cih.

\section{e. Penanganan Produk}

Penyimpanan. Sirup markisa ini dapat disimpan lama pada suhu kamar. Penanganan produk merupakan tahap yang penting karena untuk menarik kepercayaan konsumen. Penanganan dilakukan dengan mendaftarkan produk ke Balai POM. Produk yang dihasilkan harus memenuhi persyaratan Sertifikasi Produksi Pangan Industri Rumah Tangga ( SPP-IRT). Produk yang dihasilkan oleh kedua kelompok PKK dapat dilihat pada Gambar 5.

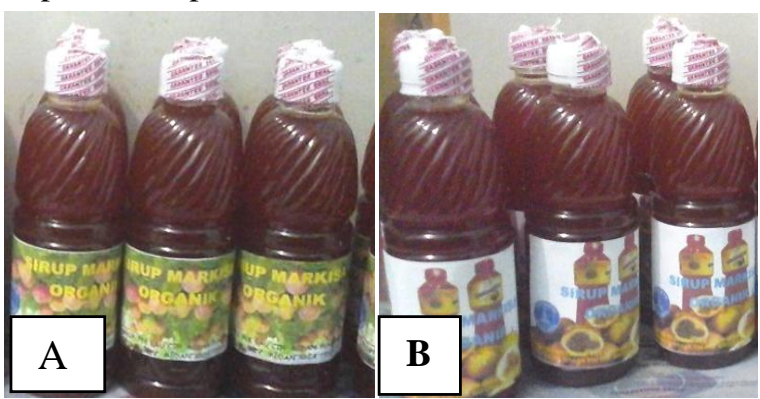

Gambar 5. Produk sirup markisa hasil kreasi kelompok PKK Lau Cih (A) dan Sidomulyo (B)

\section{Pembuatan Masker Limbah Buah markisa}

Kulit markisa dan biji markisa dapat digunakan sebagai bahan dalam pembuatan masker atau yang disebut bedak dingin tradisional alami kulit markisa dengan tahap-tahap sebagai berikut: Pertama-tama menyiapkan bahan-bahan untuk membuat bedak dingin tradisional terlebih dahulu yaitu: Kulit buah markisa segar sebanyak $250 \mathrm{~g}$, beras organik $125 \mathrm{~g}$, air 50 ml. Untuk takaran bahan-bahan diatas menyesuaikan dengan jumlah banyaknya bedak dingin tradisional yang ingin dibuat. Alat-alat yang digunakan: Mangkuk atau ember kecil, blender, atau bisa juga ulekan untuk menumbuk dan alat penyaring. Kegiatan yang selanjutnya dilakukan adalah:

1) Kulit markisa dipotong-potong dengan ukuran 1 $\mathrm{cm} \times 1 \mathrm{~cm}$.

2) Sebanyak $250 \mathrm{~g}$ kulit markisa yang telah dipotong ukuran $1 \mathrm{~cm} \mathrm{x} 1 \mathrm{~cm}$ ditambah $100 \mathrm{ml}$ air.

3) Menghaluskan kulit markisa dengan cara di blender selama 5 menit, jika blender tidak ada maka kulit markisa dapat di tumbuk hingga halus. 
4) Merendam 2 - 3 genggam beras organik tanpa pemutih selama 1-3 malam.

5) Memisahkan beras dengan air menggunakan alat penyaring.

6) Beras diblender hingga halus.

7) Mencampur hasil blender kulit markisa dengan tepung beras organik dengan takaran menyesuaikan sampai menjadi adonan seperti kue dengan bentuk bulat-bulat.

8) Agar bisa lebih tahan lama jemurlah adonan bulat-bulat tersebut pada terik sinar matahari dan bedak dingin pun telah jadi dan siap untuk digunakan.

9) Bedak dingin dikemas menggunakan kantong plastik ukuran $5 \mathrm{~cm}$ x $15 \mathrm{~cm}$ lalu di sealer menggunakan sealer listrik.

\section{HASIL DAN PEMBAHASAN}

Secara umum kegiatan pengabdian kepada masyarakat ini (PPM IbM) direspon baik oleh kedua kelompok PKK. Setiap peserta mengikuti dengan seksama penjelasan tahapan pembuatan sirup markisa dan pengolahan limbahnya serta berpartisipasi aktif dalam diskusi praktek. Peserta kelompok PKK yang hadir dikedua kelurahan tersebut melebihi dari target yang telah ditetapkan (20 orang). Peserta PKK Lau Cih yang hadir sebanyak 27 orang sementara peserta PKK Sidomulyo hadir sebanyak 37 orang.

Pada kegiatan sebelumnya telah dilakukan kegiatan pengabdian kepada masyarakat di kedua kelompok PKK tersebut tentang budidaya tanaman markisa, pemeliharaan tanaman serta pengendalian hama dan penyakit tanaman markisa. Pada umumnya tanaman sudah berbuah lebat. Buah dibiarkan berjatuhan padahal buah dapat diolah menjadi bahan sirup markisa.

Kegiatan PPM IbM pengolahan sirup markisa dilaksanakan dalam bentuk pelatihan, diawali dengan ceramah dan diskusi secara teoritik, dilanjutkan dengan praktek dan bimbingan, lalu konsultasi. Dengan tahap-tahap kegiatan tersebut, peserta diharapkan memiliki pengetahuan dan keterampilan lebih dalam melakukan pengolahan sirup markisa dan pengolahan limbahnya menjadi bedak dingin.

Untuk meningkatkan kemampuan peserta dalam pengolahan buah markisa menjadi sirup dan pengolahan limbahnya maka pihak pelaksana menyiapkan materi pelatihan tentang metoda sederhana cara pembuatan sirup markisa, pembotolan, pemasangan sealaer, pelabelan dan pembuatan bedak dingin berbahan baku limbah kulit dan biji markisa. Disamping itu juga digunakan alat bantu berupa banner/poster tentang nilai ekonomis tanaman markisa dan tehnik pengolahan sirup markisa dan limbahnya. Penyampaian materi menggunakan alat bantu infocus, hal ini dilakukan guna meningkatkan tersampaikannya materi kegiatan secara tuntas kepada peserta kegiatan.
Penyuluhan merupakan cara yang paling tepat dalam memberikan pengetahuan kepada masyarakat untuk memantapkan pelaksanaan kegiatan dan hasil penyuluhan. Pada saat penyuluhan/percontohan dan pembinaan selalu diadakan diskusi dan konsultasi untuk lebih memantapkan kegiatan pengabdian kepada masyarakat yang dilaksanakan. Selain itu dilakukan pelatihan dan percontohan dengan cara memperagakan/ mempercontohkan bagaimana cara pembuatan sirup markisa yang dimulai dari pemilihan buah yang masak/tua, pencucian buah, pemotongan buah, mengekstrak isi buah, pemanasan sari buah, penambahan bahan pengawet (natrium benzoat), penambahan bahan pengental (CMC), pendinginan, pembotolan, pemasangan tutup botol dan penyegelan (sealer) serta pengolahan limbah kulit buah dan biji menjadi bedak dingin markisa.Selanjutnya anggota kelompok PKK yang telah mulai menerapkan tekhnologi ini dibimbing dengan pembinaan yang akan dilakukan secara periodik melalui koordinasi dengan ketua kelompok. Kegiatan monitoring dan evaluasi dilakukan oleh tim pelaksana dari UMA terhadap keberlanjutan usaha pengolahan sirup markisa dan bedak dingin markisa.

Pengolahan buah markisa segar menjadi sirup markisa serta pengolahan limbahnya memberikan nilai tambah bagi kedua kelompok PKK terutama pada saat panen besar yang jatuh pada bulan Nopember hingga Januari. Dengan meningkatnya pengetahuan dan keterampilan kelompok PKK maka buah markisa kuning dapat dijadikan sirup dan limbah kulit buah berhasil diolah menjadi bedak dingin markisa dengan kata lain semua bagaian dari buah markisa dapat dimanfaatkan tidak ada bagian yang terbuang. Hasil pelatihan adalah berupa produk sirup markisa dan bedak dingin markisa Pada Gambar 6 berikut ini dapat dilihat hasil produksi mitra.
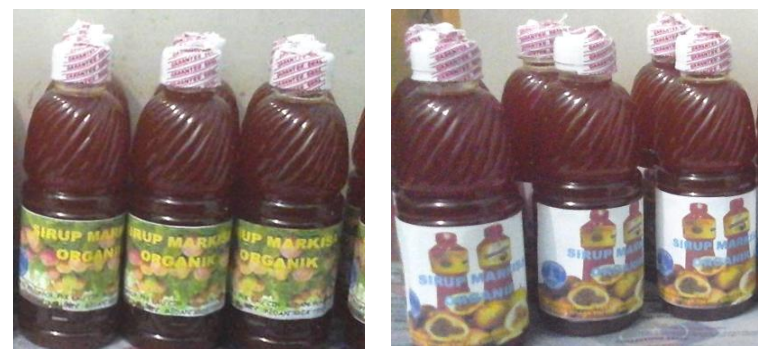

Gambar 6. Produk sirup markisa hasil kreasi kelompok PKK Lau Cih (A) dan Sidomulyo (B)

Secara umum kegiatan berhasil dengan baik, ditinjau dari manfaat yang diperoleh yaitu: 1. Mitra memiliki pengetahuan tentang pembuatan sirup markisa dan pengolahan limbahnya.2. Mitra berpartisipasi aktif pada kegiatan. 3. Mitra mampu mengolah buah markisa kuning menjadi sirup markisa. 4. Mitra mampu mengolah limbah buah markisa menjadi bedak dingin markisa. 


\section{KESIMPULAN}

Transfer IPTEKS berbasis masyarakat (IbM) dalam pengolahan buah markisa menjadi sirup markisa dan bedak dingin markisa memberikan hasil yang dirasakan manfaatnya oleh kelompok PKK Kelurahan Lau Cih dan Kelurahan Sidomulyo selain itu dapat disimpulkan bahwa:

1. Terjadi peningkatan pengetahuan dan ketrampilan peserta kelompok PKK dalam pembuatan sirup markisa dan pengolahan limbahnya menjadi bedak dingin dapat dijadikan pilihan yang menguntungkan karena buah markisa kuning yang rasanya asam dapat ditingkatkan nilainya dengan pembuatan sirup dan bedak dingin limbah markisa.

2. Diperlukan pendampingan kepada kelompok PKK secara regular (1 bulan sekali) guna memantapkan semangat yang dimiliki oleh anggota kelompok sekaligus peningkatan ketrampilan dalam budidaya tanaman markisa.

\section{Ucapan Terima Kasih Dan Penghargaan Yang} Setinggi-Tingginya Disampaikan Kepada:

1. Bapak Kemenristek Dikti atas pemberian dana hibah Pengabdian kepada Masyarakat.

2. Bapak Lurah Lau Cih, Bapak Lurah Sidomulyo yang telah memberikan dukungan dalam administratif program sosialisasi dan pelatihan pembuatan sirup markisa dan pengolahan limbahnya.

3. Ketua dan anggota Kelompok PKK Kelurahan Lau Cih dan Kelurahan Sidomulyo yang telah mengikuti kegiatan sosialisasi dan pelatihan budidaya tanaman markisa dalam pemanfaatan pekarangan.

\section{DAFTAR PUSTAKA}

Tambunan T., 2003, Analisis Terhadap Peranan Industri Kecil/Rumah Tangga di Dalam Perekonomian Regional (Suatu Studi Perbandingan Antara Kabupaten di Provinsi Jawa Barat), http://202.159.18.43/isi/4tulus.htm, Selasa 16 Agustus 2005

Tanjung, A.I. Desember 1978/Maret 1979, Cara pembuatan sirup markisa yang baik. Majalah Kimia, V (14/15),: 1-4

Anonim, 2013. Angka Sementara Hasil Sensus Pertanian 2013.Badan Pusat Statistik Kota Medan.

Anonim, 2013.2 Medan. http://www.pemkomedan.go.id/mdnttg.php, diakses 23 Februari 2014

Anonim,2013. Kecamatan Medan Tuntungan ( https://www.google.com/\#q=profil+medan+tu ntungan\&start=10, diakses 23 Februari 2014). 